\title{
Establishment of new murine embryonic stem cell lines for the generation of mouse models of human genetic diseases
}

\author{
M.A. Sukoyan ${ }^{1}$, \\ A.Y. Kerkis ${ }^{1}$, \\ M.R.B. Mellor, \\ I.E. Kerkis ${ }^{1}$ \\ J.A. Visintin ${ }^{2}$ \\ and L.V. Pereira ${ }^{1}$
}

\author{
${ }^{1}$ Departamento de Biologia, Instituto de Biociências, \\ Universidade de São Paulo, São Paulo, SP, Brasil \\ ${ }^{2}$ Departamento de Reprodução Animal, \\ Faculdade de Medicina Veterinária e Zootecnia, \\ Universidade de São Paulo, São Paulo, SP, Brasil
}

\section{Correspondence \\ Correspondence \\ L.V. Pereira \\ Departamento de Biologia \\ Instituto de Biociências, USP \\ Rua do Matão, 277 \\ 05508-900 São Paulo, SP \\ Brasil \\ Fax: +55-11-3091-7553 \\ E-mail: Ipereira@ usp.br}

Research supported by FAPESP (Nos. 96/9031-9, 98/10703-7, 98/10607-8 and 98/10606-1).

Received September 13, 2001 Accepted February 26, 2002

\begin{abstract}
Embryonic stem cells are totipotent cells derived from the inner cell mass of blastocysts. Recently, the development of appropriate culture conditions for the differentiation of these cells into specific cell types has permitted their use as potential therapeutic agents for several diseases. In addition, manipulation of their genome in vitro allows the creation of animal models of human genetic diseases and for the study of gene function in vivo. We report the establishment of new lines of murine embryonic stem cells from preimplantation stage embryos of $129 / \mathrm{Sv}$ mice. Most of these cells had a normal karyotype and an XY sex chromosome composition. The pluripotent properties of the cell lines obtained were analyzed on the basis of their alkaline phosphatase activity and their capacity to form complex embryoid bodies with rhythmically contracting cardiomyocytes. Two lines, USP-1 and USP3 , with the best in vitro characteristics of pluripotency were used in chimera-generating experiments. The capacity to contribute to the germ line was demonstrated by the USP-1 cell line. This cell line is currently being used to generate mouse models of human diseases.
\end{abstract}

\section{Key words}

- Human genetic diseases

- Murine embryonic stem cells

- Mouse model

- Transgenic mouse

\section{Introduction}

Murine embryonic stem (ES) cell lines are derived from cells isolated in vitro from the inner cell mass of blastocysts and are known to be pluripotent $(1,2)$. Pluripotency is the remarkable capacity of ES cells to resume normal development within an organism, being able to populate different tissues including the germ line. The develop- mental potential of ES cells can be evaluated by means of in vitro tests, and especially in vivo through the formation of germ-line competent chimeras. Only germ-line competent ES cell lines are considered to be highly pluripotent.

Using specific culture conditions, ES cells can be maintained in an undifferentiated state throughout multiple cell divisions, even after many passages and following genetic ma- 
nipulations (3-6). An important feature of ES cells is their ability to be induced to enter a program of differentiation in vitro. When transferred to a suspension culture, they spontaneously form aggregates of differentiating cells known as "embryoid bodies" (EBs) $(3,7-12)$. Within the EBs, a variety of early embryonic lineages (hematopoietic, neuronal, vascular endothelial, cardiac and skeletal muscle) can be identified by morphological, immunohistochemical and RT-PCR analysis (3,6,12-16). Studies of developmental gene expression in EBs indicate that derivatives of the three germ layers formed during gastrulation and early organogenesis are present in EBs. Moreover, developmental marker genes maintain in vitro the same temporal and spatial patterns of expression as observed in vivo (17).

The aforementioned properties of ES cells have led to their extensive use in developmental biology, genetics and biotechnology as an in vitro model for early embryogenesis. Presently, ES cells are used to study the mechanisms of early embryonic cell differentiation, the process and mechanisms of $\mathrm{X}$ chromosome inactivation and the effects of biologically active and toxic substances in vitro $(10,18,19)$. In addition, the ability of ES cells to differentiate into any tissue represents an enormous therapeutic potential. Induced to differentiate in vitro into specific cell types, they may be an unlimited source of tissues for transplant in the treatment of several diseases. An important development in this direction has been the recent establishment of human ES cells (20). Now, the conditions for the differentiation of murine ES cells may be adapted to the human ES cell lines.

Over the past few years ES cells have been extensively used for the production of transgenic mice as genetic models of heritable human diseases (21). The introduction of site-specific mutations into ES cells by homologous recombination permits the creation of specific genetic alterations in the mammalian genome $(22,23)$. Genetically modified ES cells, when introduced into blastocysts and transferred to a foster mother, can colonize the germ line of the resulting chimeras. Transmission of the genetic alteration by breeding leads to the production of mutant animals, the so-called knockout mice $(22,24)$, powerful tools for the study of gene function in vivo.

Pluripotency is a critical parameter of ES cell lines used in transgenesis. During in vitro cultivation, loss of pluripotency of ES cells may occur. The use of aged ES cell lines can lead to low gene targeting frequency and to poor germ-line contribution in chimeras $(5,25)$. Commercial murine ES cells are usually expensive and can be used during a limited period of time due to their aging. Thus, to generate transgenic animals it is important to obtain new highly pluripotent germ-line competent ES cell lines to be used in the earliest passages.

In the present study we report the establishment of eight new ES cell lines from a mouse $129 / \mathrm{Sv}$ substrain. Their pluripotency was evaluated in vitro using conventional tests. The ability of two cell lines to produce germ-line competent chimeras was tested in vivo. One ES cell line was demonstrated to be germ-line competent.

\section{Material and Methods}

\section{Establishment of embryonic stem cell lines}

ES cell lines were obtained using an adaptation of the protocol (26). Embryos were flushed from the uterus of mice of the 129/ Sv substrain (white-bellied agouti with dark eyes) in a stage of early blastocyst (3.5 days postcoitum, dpc). Embryos were separated from zonae pellucidae using acidic Tyrode solution (Sigma, St. Louis, MO, USA). They were then added to 4-well plates onto $\gamma$ irradiated mouse primary embryonic fibroblasts used as a feeder layer, in ES cell media [Dulbecco's modified Eagle's medium (high 
glucose; Gibco, Gaithersburg, MD, USA) supplemented with $15 \%$ fetal bovine serum (FBS; HyClone, Logan, UT, USA), $1 \mathrm{mM}$ sodium pyruvate, 1\% MEM nonessential amino acids, $1 \times 10^{3} \mathrm{U} / \mathrm{ml}$ murine leukemia inhibitory factor (ESGRO-LIF; Gibco), 0.1 $\mathrm{mM}$ B-mercaptoethanol, $50 \mathrm{U} / \mathrm{ml}$ penicillin, and $50 \mu \mathrm{g} / \mathrm{ml}$ streptomycin]. After 3-4 days, clumps of cells derived from the inner cell mass were recovered with a capillary pipette, disaggregated in drops of $0.25 \%$ trypsin-EDTA solution and replated. Morphologically ES cell-like colonies consisting of small juxtaposed spheroid cells with big nuclei were selected after 3-5 days of culture, disaggregated as described above, and transferred to $35-\mathrm{mm}$ plates (passage 1). The feeder layer of embryonic fibroblasts was always used in ES cell cultivation. For further passages, culture flasks of $25 \mathrm{~cm}^{2}$ were used. ES cells were incubated at $37^{\circ} \mathrm{C}$ with $5 \% \mathrm{CO}_{2}$ and high humidity. Replating was performed every 2-3 days, when ES cells reached $70-80 \%$ confluence. Medium was changed daily. Cells were frozen in ES cell medium containing 20\% FBS and 10\% DMSO at $-70^{\circ} \mathrm{C}$, and transferred to liquid $\mathrm{N}_{2}$ after $24 \mathrm{~h}$.

\section{Cytogenetic analysis}

Cytogenetic analysis of all ES cell lines was carried out using the protocol of Hogan et al. (27). Metaphase spreads were treated and stained by the trypsin-Giemsa banding technique. At least 50 metaphases from each cell line were studied in order to establish their chromosome number. The replicative state of the $\mathrm{X}$ chromosomes was analyzed using 5-bromodeoxyuridine (BrdU) as described (28).

\section{Alkaline phosphatase activity}

ES cells growing on feeder layer on microscope slides were fixed and stained as described (29). Alkaline phosphatase activ- ity was estimated by visual analysis of stained cells.

Embryoid body generation. ES cells were grown to near confluence, removed gently with $0.25 \%$ trypsin-EDTA solution and diluted to a concentration of $1 \times 10^{6}$ cells $/ \mathrm{ml}$ with ES cell medium. To separate small aggregates of ES cells from the embryonic fibroblasts, the suspension was left in the culture flask in the $\mathrm{CO}_{2}$ incubator for $15 \mathrm{~min}$ for fibroblast attachment. Then, about $0.3 \mathrm{ml}$ of the fibroblast-free suspension diluted with $3 \mathrm{ml}$ of ES cell medium without murine leukemia inhibitory factor and B-mercaptoethanol was added to $35-\mathrm{mm}$ plates coated with $1 \%$ agarose and incubated in the $\mathrm{CO}_{2}$ incubator. The medium was changed every 2-3 days. EB development and morphology were observed by confocal microscopy.

\section{Strains of mice used for embryos}

Mice of the CD-1 strain were housed in cabinets under controlled light temperature conditions. Superovulation of females was performed using 5 IU of pregnant mare serum gonadotropin followed 44-48 $\mathrm{h}$ later by $5 \mathrm{IU}$ of human chorionic gonadotropin.

\section{Production of chimeras}

Chimeras were generated by aggregation of ES cells with compact morulae according to published protocols (30). Embryos at 2.5 dpc were flushed from oviducts, washed in M16 medium and transferred to a drop of acidic Tyrode solution for 1.0-1.5 min until removal of the zona pellucida. The embryos were immediately washed in two drops of M16 medium. Approximately 20-30 ES cells were placed onto each embryo nested in individual microwells (standard 96-microwell plate) using a silicone-treated capillary. To provide a closer contact between embryo and ES cells the depression was made at the bottom of the microwell with a needle. They were cultured in M16 medium at $37^{\circ} \mathrm{C}$ in $5 \%$ 
Figure 1. Number of chromosomes in embryonic stem (ES) cell lines determined by cytogenetic analysis.
Figure 2. Alkaline phosphatase activity in embryonic stem (ES) cells. A, USP-2 (A414); B, B220. Undifferentiated ES cells (star) are stained positively and the feeder layer fibroblasts (arrows) and differentiated ES cells (triangle) are not stained.
$\mathrm{CO}_{2}$ in air in a high humidity incubator for 24 h. Well-developed morphologically normal blastocysts were transferred to the uteri (5-6 blastocysts per corn) of pseudopregnant CD1 recipients at $3.5 \mathrm{dpc}$.
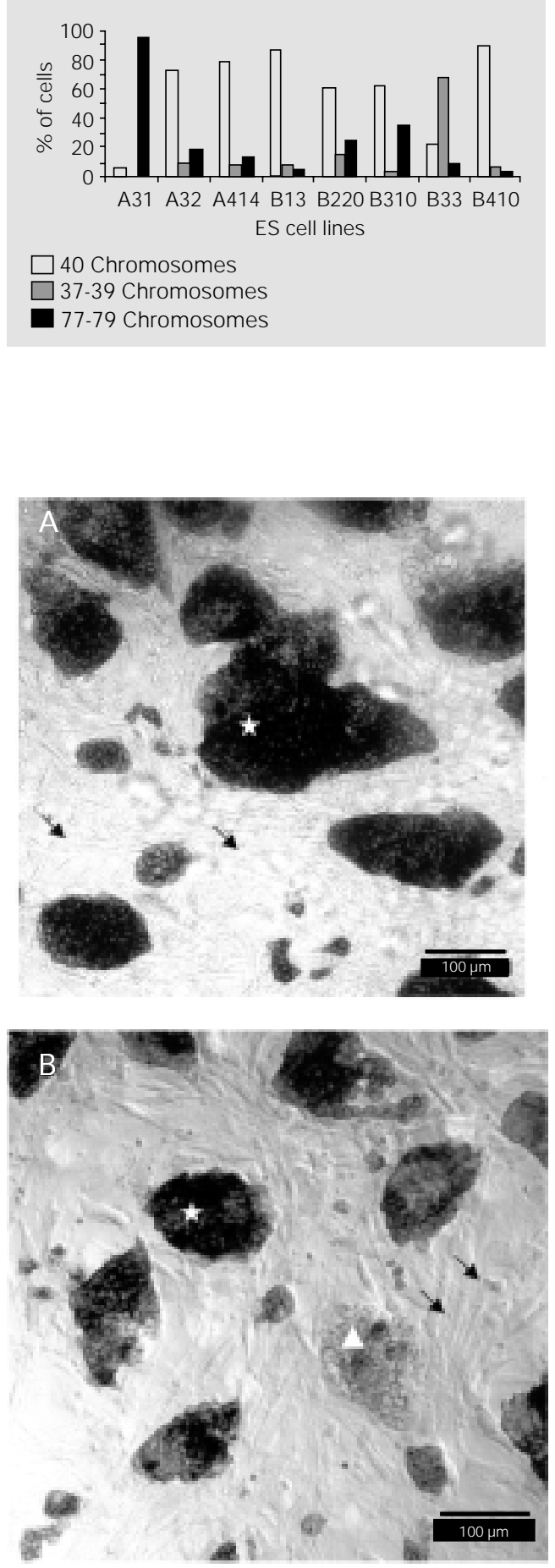

\section{Results and Discussion}

Eight independent ES cell lines were obtained from 40 blastocysts from 129/Sv mice. Cytogenetic analysis revealed a near diploid chromosome number in all but one line (A31) (Figure 1). This line had more than $90 \%$ of near tetraploid $(2 n=77-80)$ karyotypes. ES cell lines having more than $40 \%$ of cells with a normal karyotype have been suggested to be efficient for germ-line transmission due to successful segregation of chromosomes throughout meiosis (31-33). The majority of our ES cell lines had a normal karyotype in more than $60 \%$ of cells (Figure 1).

The sex chromosome composition of six established ES cell lines was XY in 100\% of cells. Two lines, B33 and A31, were XO and XXXX, respectively (data not shown). ES cell lines with $\mathrm{XY}$ composition have been shown to be the best for use in transgenic experiments since they generate chimeric males which can produce a large number of offspring (34).

The ability of ES cells to form simple and complex EBs is also an important criterion for the evaluation of their pluripotency in vitro. Simple EBs at day 2-3 of development have an external layer of endoderm-like cells and a central part of ectoderm-like undifferentiated cells. In complex EBs, the ectoderm layer may develop into multiple cell lineages with spontaneously beating cardiomyocytes in some of them, demonstrating an advanced degree of differentiation $(3,4,12,35)$. ES cell lines able to form only simple EBs were considered to have restricted pluripotency. All established cell lines were capable to form simple EBs. Two lines, A31 and B220, failed to form complex EBs. In lines A32, B310, B410 and A414, the quantity of pulsing EBs was the greatest, suggesting cardiomyocyte differentiation within the EBs.

Alkaline phosphatase activity of the cells was examined to test their ability to maintain the undifferentiated status during in vitro cultivation. Strong positive staining for alka- 
line phosphatase was revealed in lines A32, A414, B310 and B410 in almost all of the cells (Figure 2A, Table 1). In lines B13, B33 and B220, about $50 \%$ of the cells were not stained or were weakly stained (Figure 2B, Table 1). It is interesting to note that the tetraploid line A31 demonstrated strong positive staining for alkaline phosphatase, which means that it is composed of undifferentiated cells. The undifferentiated status of female ES cells was also confirmed by analysis of the inactivation status of $\mathrm{X}$ chromosome activity (28). The BrdU staining of $\mathrm{X}$ chromosomes of the A31 cell line was negative, indicating that all four $\mathrm{X}$ chromosomes were active, a condition suggestive of undifferentiated cells (data not shown).

Summarizing the data obtained, we conclude that among eight established ES cell lines, four (A32, A414, B310 and B410) showed good morphology, a high percentage of cells with a normal karyotype and a high level of pluripotency tested in vitro. Due to their in vitro characteristics, these lines can be used in chimera-generating experiments and germ-line transmission tests. These four lines, A32, A414, B310 and B410, were named USP-1, USP-2, USP-3 and USP4 , respectively.

The germ-line competence of two lines, USP-1 and USP-3, was tested in vivo by production of chimeric animals by aggregation of these cells with preimplantation embryos. Since the aggregation method was first established $(25,30)$, it suffered various modifications introduced by other investigators, but the basic principles were retained (36-38). This procedure involves co-culture of ES cells with zona pellucida-free morulae ( 8 to 16 cells) in microwells, providing close contact between them. The degree of ES cell integration into morulae after overnight culturing varies significantly and is reflected on the level of chimerism of the resulting animals.

In our experiments, morulae were flushed from oviducts of CD-1 mice after superovu- lation. Each morula selected for the experiment was aggregated with 20-30 ES cells. Following overnight culturing, 21 morulae aggregated with USP-1 cells and 50 morulae aggregated with USP-3 cells developed into blastocysts without visible morphological defects. The blastocysts were then transferred to five recipient mothers and 5/21 and 16/50 newborns were obtained. Five of these newborns ( 2 females and 3 males) were chimeric by coat color and had black eyes. The level of chimerism varied from 20 to $100 \%$ (Figure 3).

Two males derived from the USP-1 cell line with highest level of chimerism (more

Table 1. Testing of pluripotency of embryonic cell lines in vitro.

\begin{tabular}{lcccc}
\hline Lines & $\begin{array}{c}\text { Representation of } \\
\text { cells with AP activity } \\
\text { in passages 3-6 }\end{array}$ & \multicolumn{3}{c}{ Types of embryoid body formation } \\
\cline { 3 - 5 } & & Simple & $\begin{array}{c}\text { Complex without } \\
\text { pulsing }\end{array}$ & $\begin{array}{c}\text { Complex with } \\
\text { pulsing }\end{array}$ \\
\hline A31 & +++ & $X$ & - & - \\
A32 (USP-1) & +++ & $X$ & $X$ & X \\
A414 (USP-2) & +++ & $X$ & $X$ & X \\
B13 & ++ & $X$ & - & - \\
B220 & ++ & $X$ & $X$ & - \\
B310 (USP-3) & +++ & $X$ & $X$ & X \\
B33 & ++ & $X$ & $X$ & X \\
B410 (USP-4) & +++ & $X$ & $X$ & $X$ \\
\hline
\end{tabular}

++ : about $70-80 \%$ of cells in culture express alkaline phosphatase (AP). $+++: 95-100 \%$ of cells in culture express alkaline phosphatase.

$\mathrm{X}$ : the cell line formed the corresponding type of embryoid bodies.

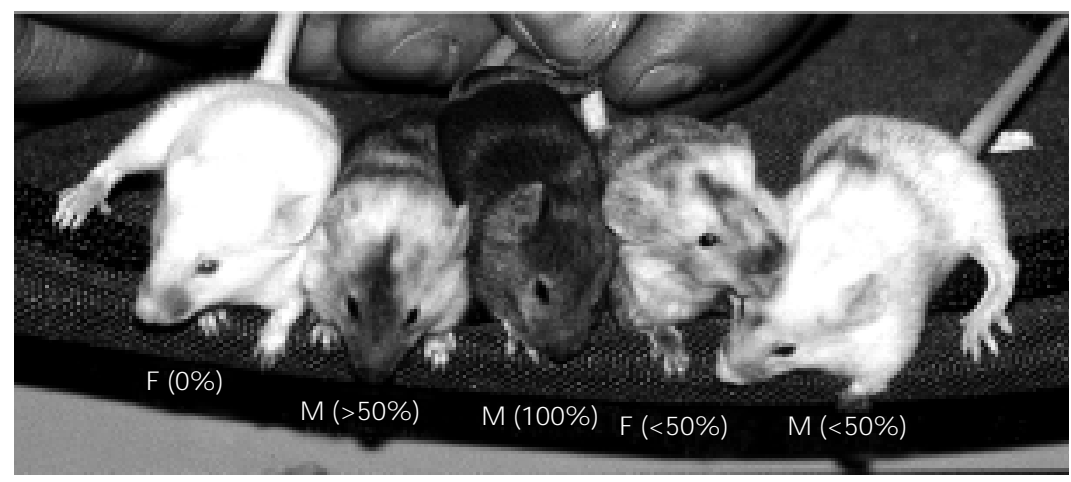

Figure 3. Chimeric animals obtained after aggregation of compacted morulae derived from CD-1 strain with USP-1 embryonic stem cell line. Percentages refer to the levels of coat color chimerism in each animal. M: male; F: female. 
Table 2. Results of aggregation of several embryonic stem (ES) cell lines with morulae from different mouse strains obtained in independent experiments.

\begin{tabular}{|c|c|c|c|c|c|c|}
\hline \multirow{2}{*}{$\begin{array}{l}\text { ES cell lines } x \text { morulae } \\
\text { of different mouse strains }\end{array}$} & \multirow{2}{*}{$\begin{array}{l}\text { Embryos } \\
\text { transferred }\end{array}$} & \multirow[t]{2}{*}{ Newborns } & \multicolumn{2}{|c|}{ Chimeras } & \multirow{2}{*}{$\begin{array}{l}\text { Germ-line } \\
\text { transmission }\end{array}$} & \multirow[t]{2}{*}{ References } \\
\hline & & & M & $\mathrm{F}$ & & \\
\hline $\mathrm{R} 1 \times \mathrm{CD}-1$ & 321 & $89(28)$ & $31(9.6)$ & $1(0.3)$ & $11(3.4)$ & 30 \\
\hline CCE $\times$ CFLP & 40 & $15(37)$ & $4(10)$ & $2(5)$ & $2(5)$ & 30 \\
\hline$\pi T 2 \times C D-1$ & 111 & $41(36)$ & $6(54)$ & $1(0.9)$ & $2(1.8)$ & 36 \\
\hline $\mathrm{R} 1 \times \mathrm{C} 57 \mathrm{BL} / 6$ & 29 & $12(41)$ & \multicolumn{2}{|c|}{$6(M+F)(20.6)$} & - & 38 \\
\hline $\mathrm{R} 1 \times \mathrm{FVB} / \mathrm{N}$ & 59 & $8(13.5)$ & \multicolumn{2}{|c|}{$6(M+F)(10.1)$} & - & 38 \\
\hline RW4 x C57BL/6 morulae & 60 & $23(38)$ & \multicolumn{2}{|c|}{$18(\mathrm{M}+\mathrm{F})(30)$} & - & 38 \\
\hline $1 \times$ CD-1 & 201 & $24(12)$ & $10(5)$ & $1(0.5)$ & $7(3.5)$ & 37 \\
\hline USP-1 x CD-1 & 21 & $5(24)$ & $2(10)$ & $2(10)$ & $2(10)$ & Present study \\
\hline USP-3 x CD-1 & 50 & $16(33)$ & $1(2)$ & & - & Present study \\
\hline
\end{tabular}

M: male; F: female. Percentages are relative to the number of embryos transferred (in parentheses).

than $50 \%$ ) were back-crossed with CD-1 females to test for ES cell colonization of the germ line. They produced 47 agouti coat color offspring, demonstrating germ-line transmission of the USP-1 ES cell line. One male with a low level of coat color chimerism, derived from the ES cell line USP-3, did not produce agouti coat color newborns, suggesting the absence of ES cell colonization of the germ line.

The data presented in Table 2 show the results of our experiments in comparison with those obtained by other authors in independent experiments. According to these data, the USP-1 ES cell line had a good rate of production of newborns (24\%) and chimeras $(10 \%)$, and an elevated rate of germline transmitters $(10 \%)$ in comparison with ES cell lines used by other authors. Thus, we have shown that the USP-1 ES cell line can be considered for use in gene targeting experiments.

We are now at a historical milestone in the completion of the human genome sequence with the identification of the 30,00040,000 human genes $(39,40)$. These data will have an enormous impact on the management of human disease. However, as with all genome projects, upon completion and identification of the corresponding transcrip- tomes, the next challenge is to determine gene function. One powerful approach for the study of gene function in vivo is the generation of mutants. In the case of human genes, mouse models are mostly used due to our extensive capability of manipulating the mouse genome by homologous recombination in ES cells. Moreover, these animals serve as models in which to study the progression of and potential therapies for human genetic diseases. We have established four new lines of highly pluripotent ES cells. Successful gene targeting has been performed in the USP-1 cell line, and the targeted clone has generated a line of Fbn1 knockout mice (data not shown). These cell lines will be used for the study of cell differentiation in culture and for the generation of mouse models for human genetic diseases. In addition, the same technology used for the establishment of murine ES cell lines may be adapted for the establishment of ES cell lines from other species, swine and cattle in particular, for biotechnological applications. Finally, once a Brazilian legislation on the use of human preimplantation embryos for research is created, the establishment of human ES cell lines will represent an important development in the field of cell transplant-based therapy. 


\section{References}

1. Evans M \& Kaufman M (1981). Establishment in culture of pluripotential cells from mouse embryos. Nature, 292: 154-156.

2. Martin GR (1981). Isolation of a pluripotent cell line from early mouse embryos cultured in medium conditioned by teratocarcinoma stem cells. Proceedings of the National Academy of Sciences, USA, 78: 7634-7638.

3. Doetschman $T$, Eistetter $H$, Katz $M$, Schmidt W \& Kemler R (1985). The in vitro development of blastocyst-derived embryonic stem cell lines: formation of visceral yolk sac, blood islands and myocardium. J ournal of Embryology and Experimental Morphology, 87: 27-45.

4. Suda Y, Suzuki M \& Aizava S (1987). Mouse embryonic stem cells exhibit indefinite proliferative potential. J ournal of Cellular Physiology, 133: 197-201.

5. Gardner RL \& Brook FA (1997). Reflections on the biology of embryonic stem (ES) cells. International J ournal of Developmental Biology, 41: 235-243.

6. Wang ZQ, Kiefer F, Urbanek P \& Wagner EF (1997). Generation of completely embryonic stem cell-derived mutant mice using tetraploid blastocyst injection. Mechanisms of Development, 62: 137145.

7. Martin GR \& Evans MJ (1975). Differentiation of clonal lines of teratocarcinoma cells: formation of embryoid bodies in vitro. Proceedings of the National Academy of Sciences, USA, 72: 1441-1445.

8. Robertson EJ (1987). Embryo-derived stem cell lines. In: Robertson EJ (Editor), Teratocarcinomas and Embryonic Stem Cells. A Practical Approach. IRL Press, Oxford, England.

9. Chen U (1992). Differentiation of mouse embryonic stem cells to lympho-hematopoietic lineages in vitro. Developmental Immunology, 2: 29-50.

10. Keller GM (1995). In vitro differentiation of embryonic stem cells. Current Opinion in Cell Biology, 7: 862-869.

11. Coucouvanis E \& Martin GR (1995). Signals for death and survival: A two-step mechanism for cavitation in the vertebrate embryo. Cell, 83: 279-287.

12. Bautch VL, Stanford WL, Rapoport R, Russel S, Byrum RS \& Futch TA (1996). Blood island formation in attached cultures of murine embryonic stem cells. Developmental Dynamics, 205: 1-12.

13. Maltsev VA, Wobus AM, Rohwedel J, Bader M \& Hescheler J (1994). Cardiomyocytes differentiated in vitro from em- bryonic stem cells developmentally express cardiac-specific genes and ionic currents. Circulation Research, 75: 233-244.

14. Bain G, Kitchens D, Yao M, Huettner J E \& Gottlieb DI (1995). Embryonic stem cells express neuronal properties in vitro. Developmental Biology, 168: 342-357.

15. Fraichard A, Chassande $O$, Bilbaut $G$, Dehay C, Savatier P \& Samarut J (1995). In vitro differentiation of embryonic stem cells into glial cells and functional neurons. J oumal of Cell Science, 108: 31813188.

16. Ling $\vee \&$ Neben $S$ (1997). In vitro differentiation of embryonic stem cells: immunophenotypic analysis of cultured embryoid bodies. J ournal of Cellular Physiology, 171: 104-105.

17. Leahy A, Xiong J W, Kuhnert $F$ \& Stuhlmann H (1999). Use of developmental marker genes to define temporal and spatial patterns of differentiation during embryoid body formation. J ournal of Experimental Zoology, 284: 67-81.

18. Heard $E$, Mongelard $F$, Arnaud $D$, Chureau C, Vourc'h C \& Avner P (1999). Human XIST yeast artificial chromosome transgenes show partial $X$ inactivation center function in mouse embryonic stem cells. Proceedings of the National Academy of Sciences, USA, 96: 6841-6846.

19. Thomson J A, Itskovitz-Eldor J Shapiro SS, Waknitz MA, Swiegiel J J, Marshall VS \& J ones J M (1998). Embryonic stem cell lines derived from human blastocysts. Science, 282: 1145-1147.

20. Thomson J A \& Odorico J S (2000). Human embryonic stem cell and embryonic germ cell lines. Trends in Biotechnology, 18: 53-57.

21. Clarke AR (1994). Murine genetic models of human disease. Current Opinion in Genetics and Development, 4: 453-460.

22. Capecchi MR (1989). The new mouse genetics: Altering the genome by gene targeting. Trends in Genetics, 5: 70-76.

23. Robertson EJ (1991). Using embryonic stem cells to introduce mutations into the mouse germ line. Biology of Reproduction, 44: 238-245.

24. Gossler A, Doetschman T, Korn R, Serfling E \& Kemler R (1986). Transgenesis by means of blastocyst-derived embryonic stem cell lines. Proceedings of the $\mathrm{Na}$ tional Academy of Sciences, USA, 83: 9065-9069.

25. Nagy A, Rossant J, Nagy R, AbramovNewerly W \& Roder J C (1993). Derivation of completely cell culture-derived mice from early-passage embryonic stem cells. Proceedings of the National Academy of Sciences, USA, 90: 8424-8428.

26. Hogan $B$, Beddington $R$, Costantini $F \&$ Lacy E (1994). Manipulating the Mouse Embryo: A Laboratory Manual. 2nd edn. Cold Spring Harbor Laboratory Press, New York, NY, USA, 254-290.

27. Hogan $B$, Beddington $R$, Costantini $F \&$ Lacy $E$ (1994). Manipulating the Mouse Embryo: A Laboratory Manual. 2nd edn. Cold Spring Harbor Laboratory Press, New York, NY, USA, 311-315.

28. Takayama S \& Matsumoto K (1982). GBand-like structures and centromeric asymmetry in the BrdU containing mouse chromosomes. Chromosoma, 85: 583590.

29. Talbot NC, Rexrod CE, Pursel V \& Powell AM (1993). Alkaline phosphatase staining of pig and sheep epiblast cells in culture. Molecular Reproduction and Development, 36: 139-147.

30. Wood AS, Pascoe WS, Schmidt C, Kemler R, Evans MJ \& Allen ND (1993). Simple and efficient production of embryonic stem cell-embryo chimeras by coculture. Proceedings of the National Academy of Sciences, USA, 90: 4582-4585.

31. Delhaise F, Bralion V, Schuurbiers $N$ \& Dessy F (1996). Establishment of an embryonic stem cell line from 8-cell stage mouse embryos. European J ournal of Morphology, 34: 237-243.

32. Suzuki H, Kamada N, Ueda O, J ishage $K$, Kurihara $\mathrm{H}$, Terauchi $\mathrm{Y}$, Azuma S, Kadowaki T, Kodama T, Yazaki Y \& Toyoda Y (1997). Germ-line contribution of embryonic stem cells in chimeric mice: influence of karyotype and in vitro differentiation ability. Experimental Animals, 46: 1723.

33. Longo L, Bygrave A, Grossveld FG \& Pandolfi PP (1997). The chromosome make-up of mouse embryonic stem cells is predictive of somatic and germ cell chimaerism. Transgenic Research, 6: 321328.

34. Mullen RJ \& Whitten WK (1971). Relationship of genotype and degree of chimerism in coat color to sex ratios and gametogenesis in chimeric mice. J ournal of Experimental Zoology, 178: 165-176.

35. Chen U \& Kosco M (1993). Differentiation of mouse embryonic stem cells in vitro: III. Morphological evaluation of tissues developed after implantation of differentiated mouse embryoid bodies. Developmental Dynamics, 197: 217-226. 
36. Goto $Y$, Sugiyama $Y$, Tanimoto $K$, Ishida J , Syoji M, Takahashi A, Sugiyama Y, Muracami K, Fukamizu A \& Yagami K (1995). Evaluation of coculture aggregation with TT2 cells for production of germline chimera. Laboratory Animal Science, 45: 601603.

37. Orimo A, Tominaga N, Suzuki M, Kawakami T, Kuno J, Sato M, Minowa O, Inoue
S, Kato S, Noda T \& M uramatsu M (1998). Successful germ-line transmission of chimeras generated by coculture aggregation with J 1 ES cells and eight-cell embryos. Analytical Biochemistry, 269: 204207.

38. Khillan J S \& Bao Y (1997). Preparation of animals with a high degree of chimerism by one-step coculture of embryonic stem cells and preimplantation embryos. Biotechniques, 22: 544-549.

39. Venter J C, Adams MD, Myers EW, et al. (2001). The sequence of the human genome. Science, 291: 1304-1351.

40. International Human Genome Sequencing Consortium (2001). Initial sequencing and analysis of the human genome. Nature, 409: 860-921. 